\title{
Seismic vulnerability of the Himalayan half-dressed rubble stone masonry structures, experimental and analytical studies
}

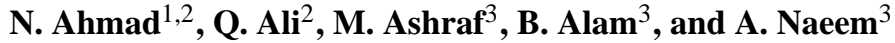 \\ ${ }^{1}$ ROSE School-IUSS Pavia, Pavia, Italy \\ ${ }^{2}$ Earthquake Engineering Center, University of Engineering \& Technology (UET), Peshawar, Pakistan \\ ${ }^{3}$ Civil Engineering Department, University of Engineering \& Technology (UET), Peshawar, Pakistan
}

Correspondence to: N. Ahmad (drnaveedahmad.eec@gmail.com)

Received: 27 April 2012 - Revised: 10 July 2012 - Accepted: 9 October 2012 - Published: 21 November 2012

\begin{abstract}
Half-Dressed rubble stone (DS) masonry structures as found in the Himalayan region are investigated using experimental and analytical studies. The experimental study included a shake table test on a one-third scaled structural model, a representative of DS masonry structure employed for public critical facilities, e.g. school buildings, offices, health care units, etc. The aim of the experimental study was to understand the damage mechanism of the model, develop damage scale towards deformation-based assessment and retrieve the lateral force-deformation response of the model besides its elastic dynamic properties, i.e. fundamental vibration period and elastic damping. The analytical study included fragility analysis of building prototypes using a fully probabilistic nonlinear dynamic method. The prototypes are designed as SDOF systems assigned with lateral, force-deformation constitutive law (obtained experimentally). Uncertainties in the constitutive law, i.e. lateral stiffness, strength and deformation limits, are considered through random Monte Carlo simulation. Fifty prototype buildings are analyzed using a suite of ten natural accelerograms and an incremental dynamic analysis technique. Fragility and vulnerability functions are derived for the damageability assessment of structures, economic loss and casualty estimation during an earthquake given the ground shaking intensity, essential within the context of risk assessment of existing stock aiming towards risk mitigation and disaster risk reduction.
\end{abstract}

\section{Introduction}

Mountainous regions in the Himalayan largely employ stone masonry in building constructions, either as load-bearing walls or as an infill in timber framing structures. For example, in Pakistan stone masonry is used in construction in 40 to 80 percent of sub-administrative units (Tehsil) of the state of Khyber Pakhtoonkhwa and Punjab (Maqsood and Schwarz, 2008). This is due to the fact that stone material is abundantly available in northern parts of Pakistan. Low-cost and lowskilled labour may be employed for construction work that consequently results in overall economical schemes.

Stone masonry buildings in the Himalayan region consist of two-wythe, load-bearing walls (Fig. 1). The void between the wythes is left empty or filled with small stones. For rural constructions, i.e. residential buildings, bearing walls are built in rubble stone masonry in which undressed stone units are laid randomly in mud mortar or simply placed in dry form, whereas half-dressed stone units laid in cement mortar are employed for urban constructions, i.e. public buildings. The buildings are provided with wooden floors in case of rural constructions, whereas reinforced concrete slab floors and roofs are used in the case of urban constructions (Ali and Mohammad, 2006; Gupta et al., 2008). The public buildings are also provided with a lightly reinforced roof band (ring beam) at the top of the walls.

Stone masonry buildings, having thick walls provided with heavy roofing, perform excellently in protecting the inside of the building from the extremity of the outside temperature and humidity, a characteristic essential in most of the Himalayan region. However, due to the low quality of construction, this structure type has performed very poorly in recent 

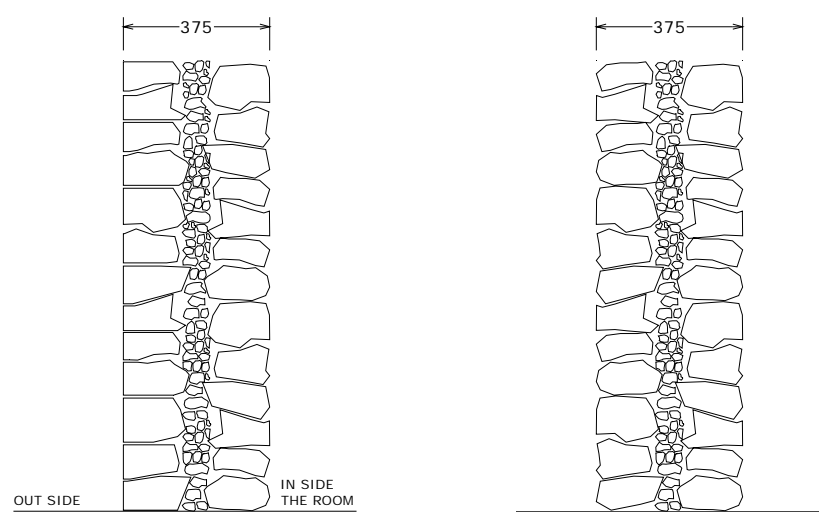

Fig. 1. Cross-section of the typical stone masonry load-bearing walls practiced in the Himalayan region. From left to right: halfdressed coursed masonry wall employed for public buildings (investigated in the present study) and undressed random masonry wall employed for rural residential buildings.

and past earthquakes (e.g., Ali and Mohammad, 2006; Bothara and Brzev, 2011; Gupta et al., 2008; Kaushik et al., 2006; Murty, 2003; Naseer et al., 2010; Rai and Murthy, 2006,). The poor performance of stone masonry buildings have also been observed in other parts of the world (Adanur, 2010; Akkar et al., 2011; Gulkan et al., 1992; Ingham and Griffith, 2011; Spence, 2007a).

Earthquakes observations may provide significant qualitative information on the earthquake resistance and vulnerability of stone masonry buildings common in the Himalayan region. However, there is very limited quantitative information available to help derive analytical fragility and vulnerability functions for half-dressed stone DS masonry in urban structures found in the Himalayan region. It is very essential to investigate this construction type, as most of the public buildings that represent critical facilities like school buildings, offices, health care units, etc., are constructed of loadbearing walls built in half-dressed stone masonry in cement mortar and are provided with reinforced concrete slab floors and roofing. In the recent 2005 Kashmir earthquake, about 19000 children unfortunately died because of the collapse of school buildings of the mentioned characteristics (EERI, 2006). The current state of geodynamic settings in the region has shown to be capable of triggering further future large earthquakes up to or even greater than a magnitude 8 (Avouac et al., 2006; Bilham, 2004), which makes it essential to assess, communicate and consequently mitigate the risk of the existing vulnerable stock.

Figure 2 reports an office building in Mansehra City of Pakistan that was moderately damaged in the 2005 Kash$\operatorname{mir} M_{\mathrm{w}}=7.6$ earthquake. Typical damages observed in the building are also described. This city was reported with an intensity of VII-VIII on the MMI scale (Javed et al., 2008). Similar types of dressed stone DS masonry buildings found in the Governor's estate in Darjeeling were damaged during the recent 2011 Sikkim earthquake in India. Typical damages observed in Darjeeling public buildings included separation at wall junctions and in-plane shear failure (EERI, 2012). The complex seismic behavior of this construction type renders its modeling timid for analytical studies. Thus, experimental investigations are essential to calibrate engineering tools and help develop simplified hypotheses for seismic analysis and vulnerability assessment of the considered construction type.

This study presents research carried out on the seismic assessment of DS masonry structures employed for public buildings (schools, offices, health care units, etc.). It is part of the research program focusing on the seismic vulnerability assessment of typical building types in the Himalayan region aiming towards risk mitigation and disaster risk reduction in the region (Ali et al., 2012). Fragility and vulnerability functions are derived herein by means of analytical and experimental investigations. The present study provides essential input for risk assessment of the considered DS masonry structures aiming towards risk mitigation (pre-event phase) and disaster risk reduction (post-event phase) in the Himalayan region in general and northern Pakistan in particular.

\section{Experimental investigation of half-dressed stone masonry model by means of dynamic shake table test}

\subsection{Aim and objective of the dynamic test}

Earthquake observations in the Himalayan region have shown very complex behavior of ruble masonry structures, including in-plane shear cracking, damage to walls from roof thrust, delamination of stone units, damage to building corners, out-of-plane bulging, collapse of walls and total collapse of structures (EERI, 2012; Javed et al., 2008; Naseer et al., 2010). This fact makes the analytical modeling of rubble stone masonry structures less confident for seismic analysis, which makes the experimental investigation essential. The aim of the dynamic test was to retrieve the elastic dynamic properties (i.e. fundamental vibration period and elastic viscous damping) of the building, understand the damage mechanism of the model, obtain lateral force-deformation response and deduce performance limits for deformation-based assessment of the building model. These properties will be employed later for analytical modeling and fragility analysis using simplified engineering tools.

\subsection{Model description}

The DS masonry structure investigated herein is a representative model of public buildings, e.g. school buildings, office buildings, health care units, etc., common in the northern areas of Pakistan. The model is designed respecting the similitude requirements for a reduced scaled Simple Model 


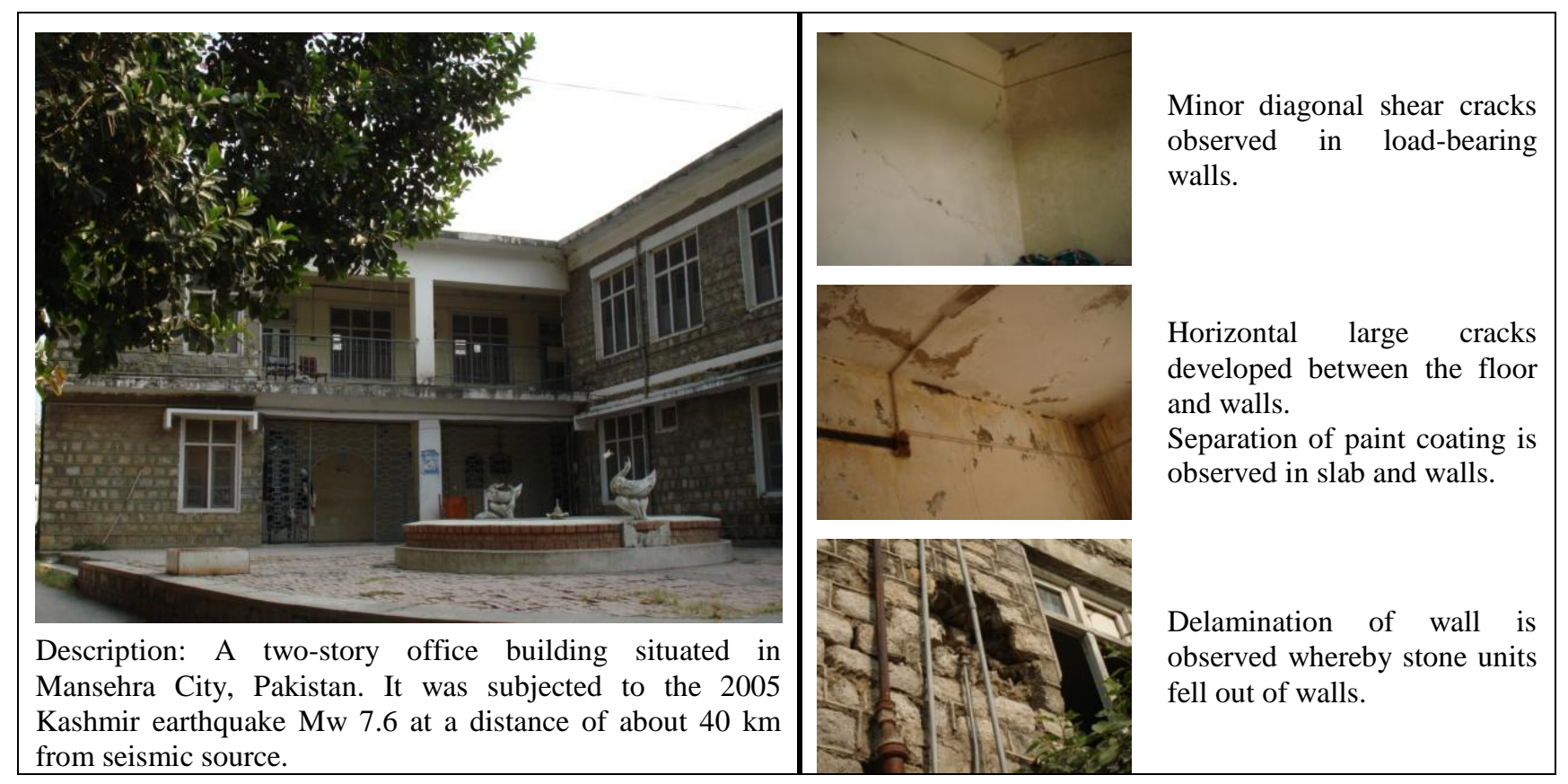

Fig. 2. A moderately damaged half-dressed stone DS masonry structure. From left to right: view of the building and description of the observed main damages in the building.

(Tomazevic, 2000; Ali et al., 2012). A scale factor of 3 is used to reduce the dimensions of the model, whereas a scale factor of 1 is used for scaling the mechanical properties (stressstrain constitutive law) of materials (stone units, mortar, masonry, concrete, steel).

Table 1 reports the characteristics of the simple model and similitude requirements for model-to-prototype conversion of quantities. Figure 3 shows details of the building model tested at the Earthquake Engineering Center of UET Peshawar.

\subsection{Testing program}

\subsubsection{Model setup and instrumentation}

The structure model was built on a strong concrete pad which was firmly connected to the shake table by means of bolts. The model was tested in the weaker direction. Three accelerometers were installed on the model: two at the base to record the input excitation and one at the roof level to record the response acceleration of the model. Four displacement transducers were installed to record the displacement time history of the model: two at the base of the model and two at the roof level. The difference of the top and bottom transducers will provide an estimate of the relative lateral deformation of the model. All the gauges were connected to a data acquisition system where the data (acceleration and displacement time history) were recorded at a time step of $0.005 \mathrm{~s}$. Cameras were installed to continuously monitor the behavior of the model. Figure 4 provides details on the instrumentation of building model.

\subsubsection{Characteristics of input excitation}

The North-South component of the Kobe 1995 record is used for the dynamic excitation of the model. The acceleration record is modified to respect the prototype to model similitude requirements (Tomazevic, 2000). The time duration and predominant period of the record was reduced by 3 . It resulted in a compressed acceleration time history with peak ground acceleration (PGA) of $0.83 \mathrm{~g}$, predominant period of $0.12 \mathrm{~s}$ and total duration of $10 \mathrm{~s}$.

\subsubsection{Testing scheme}

The model was subjected to dynamic excitation in three phases. The input excitations were designed accordingly to push the structure from elastic to inelastic to collapse state, thereby enabling the monitoring of the complete response of the model. The first phase included a low amplitude, 5 percent scaled record excitation of the model, having a PGA of $0.04 \mathrm{~g}$. This phase was mainly included to retrieve the dynamic characteristics, i.e. fundamental vibration period and viscous damping, of the model. For the second and third run, the record was scaled up in 5 percent increments in the excitation amplitude resulting in a PGA of $0.083 \mathrm{~g}$ and $0.20 \mathrm{~g}$, respectively. The model was completely collapsed in the last run. The test video can be viewed online at the 
Table 1. Characteristics of the simple test model and similitude requirements for quantities conversion.

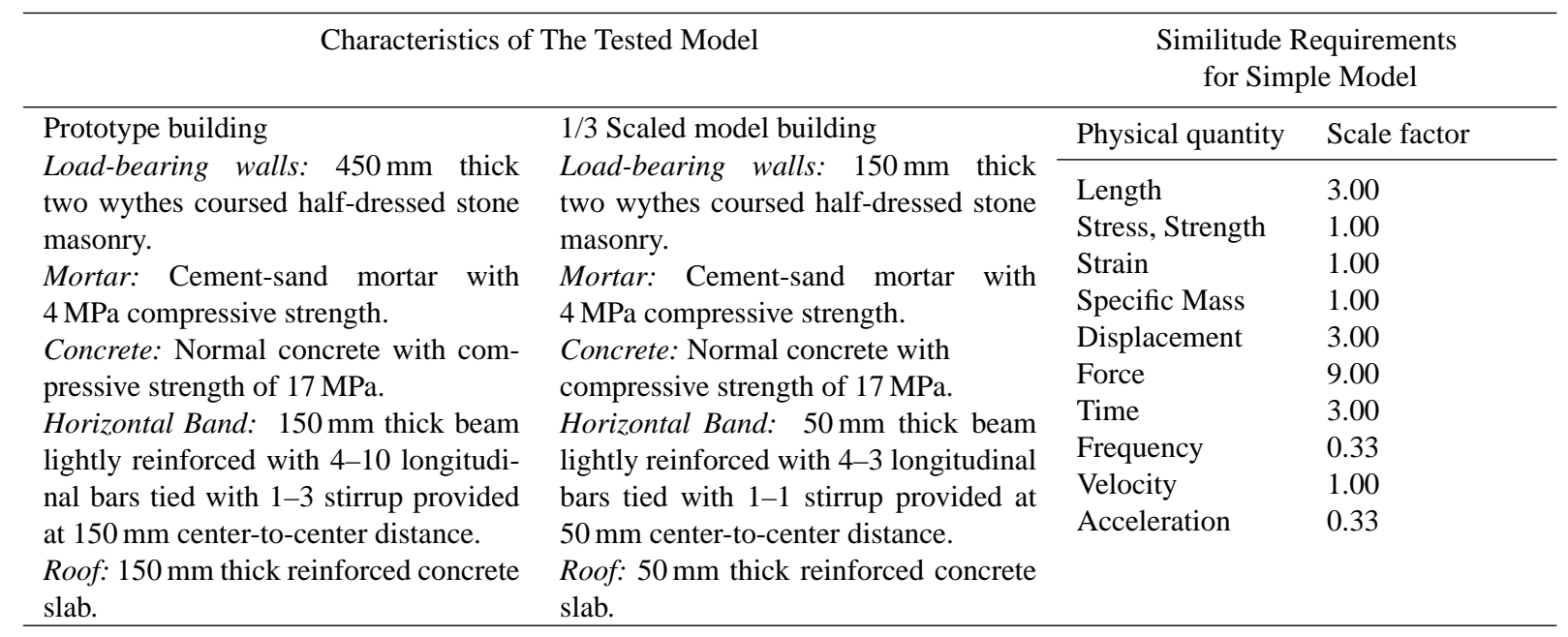
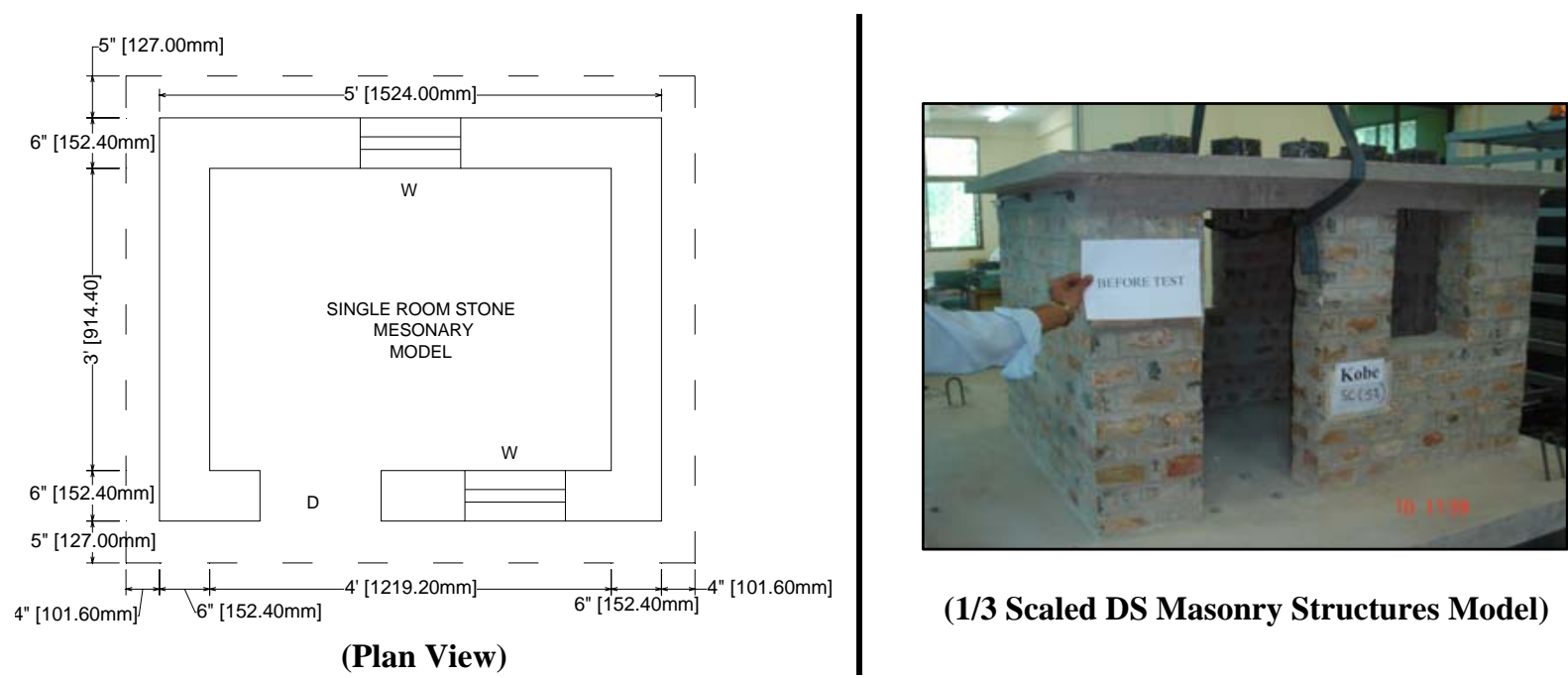

(1/3 Scaled DS Masonry Structures Model)

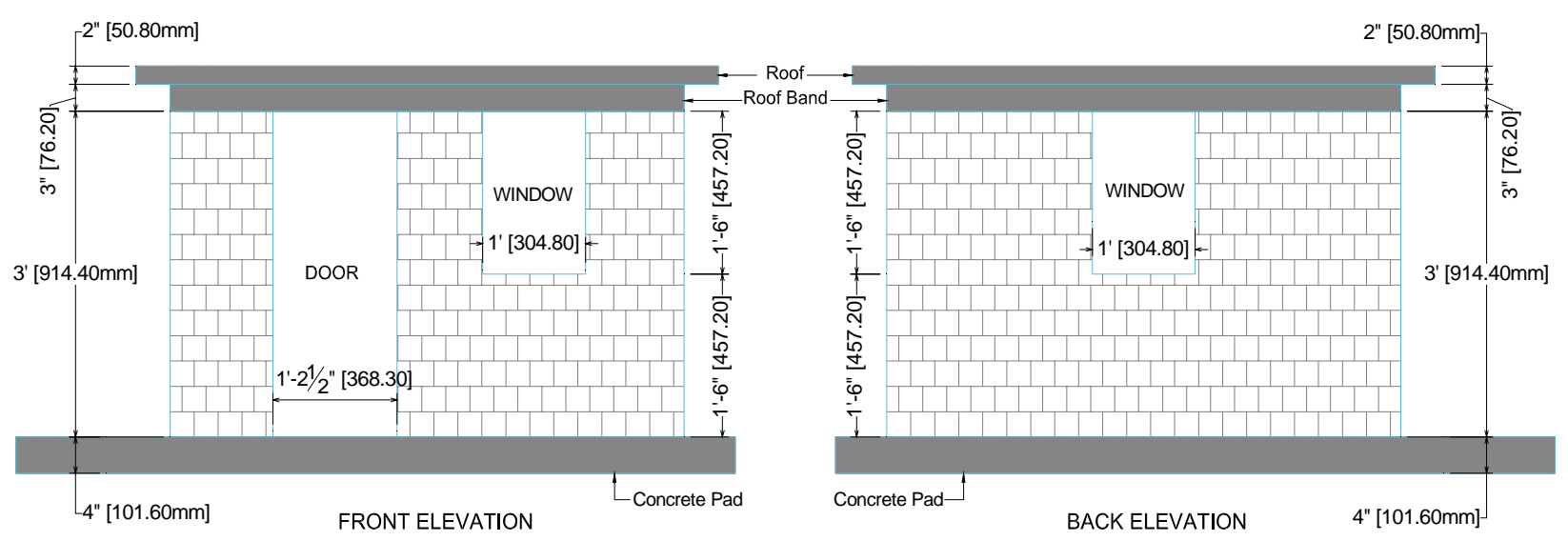

(Front and Back Elevation View)

Fig. 3. Geometric details of the structural model tested at the Earthquake Engineering Center of UET Peshawar. 
YouTube videos database maintained by EERI Institute of USA (http://www.youtube.com/watch?v=r8JDj-DFzJs).

\subsection{Observed behavior and damage mechanism}

\subsubsection{Global performance under input excitation}

The first test run at PGA of $0.04 \mathrm{~g}$ did not cause any appreciable damage in the model. The building behaved primarily in a boxlike manner. A horizontal crack was developed between the walls and ring beam during the second test run at PGA of $0.08 \mathrm{~g}$. Slight cracks were also developed in the inplane and out-of-plane walls. The building collapsed during the third test run at PGA of $0.20 \mathrm{~g}$.

\subsubsection{Observed main damages}

During the last test cracks developed in the in-plane and out-of-plane walls, which widened largely with increased shaking intensity. Damage in the in-plane walls included diagonal, horizontal and inclined pattern cracks. Horizontal and inclined cracks developed in the out-of-plane walls. The widening of cracks and separation of roof from walls upon increased shaking intensity led to extensive damage in the in-plane walls, delamination of stone units from the out-ofplane walls, damage to corners and consequent stone falling, out-of-plane collapse of walls and complete collapse of the building model. The observed behavior of the model in the initial stages were comparable with the observed damages in the recent $2005 \mathrm{Kashmir}$ earthquake for public buildings (see Fig. 2).

\subsubsection{Observed global damage mechanism and comparison with EMS-98 scale}

The behavior of the model was closely monitored during the last run to deduce damage states of the buildings and develop a damage scale towards performance-based assessment of the building for future applications. Figure 5 reports the global damage states of the building observed during the test with increased shaking level. The observed damage states are also compared with the EMS-98: European Macroseismic Scale (Grunthal et al., 1998) for masonry buildings. It is a standard scale adopted in Europe for masonry building damage rating within the context of post-earthquake screening, vulnerability and fragility analysis. It is observed that the two scales are comparable for DS1 and DS2 damage states. However, the EMS-98 damage scale seems more conservative for DS3 and DS4 limit states, i.e. the extent of building damage specified by the EMS-98 scale is more than the observed damages in the considered building. The observed damage, particularly of the floor, is different than the EMS-98 specified damage pattern. The floor for the considered building failed in an abrupt manner upon the complete damage and spalling of load-bearing walls, which is due to the rigid nature of the floor and its monolithic connection with the walls. This type of roof collapse was also observed during the 2005 Kashmir earthquake for block masonry buildings with monolithic RCC roof slab (Bothara and Brzev, 2011). Generally, the typical roof used for European masonry buildings is composed of timber, roof trusses braced with timber, covered with an iron sheet (in some cases) and roof tiles. For these types of buildings, the tiles from the roof detach in a progressing manner during earthquakes, unlike the rigid RCC slab employed for the considered buildings.

\subsubsection{Damage mechanism of component walls}

The behavior of individual component walls, i.e. in-plane walls and out-of-plane walls, were also closely monitored with increased shaking level, in order to fully understand the seismic response of each component wall. Figure 6 reports the damage mechanism and cracking propagation for each component wall. It can be observed that the response of rubble masonry structure is very complex, which is due to the random nature of rubble masonry and rough construction work.

For example, one of the piers (with similar characteristics) of the in-plane wall developed diagonal shear mechanism, whereas the other pier developed sliding and rocking mechanism, with progressing disintegration of piers. Such complex behavior, which is due to the random nature of masonry, cannot be simulated with available numerical tools and thus presents a challenge for computing tools for seismic behavior assessment of rubble stone masonry buildings. This fact also point to the importance of experimental investigation of rubble masonry buildings for understanding the seismic behavior and evaluating the seismic performance.

\subsubsection{Dynamic characteristics of the building model: walls}

The low amplitude input excitation (PGA $0.04 \mathrm{~g}$ ) was primarily meant to help retrieve the elastic dynamic properties of the model, including fundamental vibration period $T_{0}$ and damping coefficient $\zeta$. Both the vibration period $T_{0}$ and damping were obtained from the response acceleration time history (Fig. 7). The period is obtained using the basic definition of period of an oscillating body (i.e. the time required for a complete oscillation). An average value of $0.07 \mathrm{~s}$ is obtained for the vibration period. The decay function for the time history of the response acceleration as proposed by Chopra (2003) is used to calculate the model damping

$\zeta=\frac{1}{2 n \pi} \operatorname{Ln}\left(\frac{A_{1}}{A_{n}}\right)$,

where $\zeta$ represents elastic damping coefficient; $A_{1}$ represents the peak amplitude of response acceleration at reference point $1 ; A_{n}$ represents the peak amplitude of response acceleration at reference point after $n$ cycles; and $n$ represents the number of cycles between the peaks. The model 


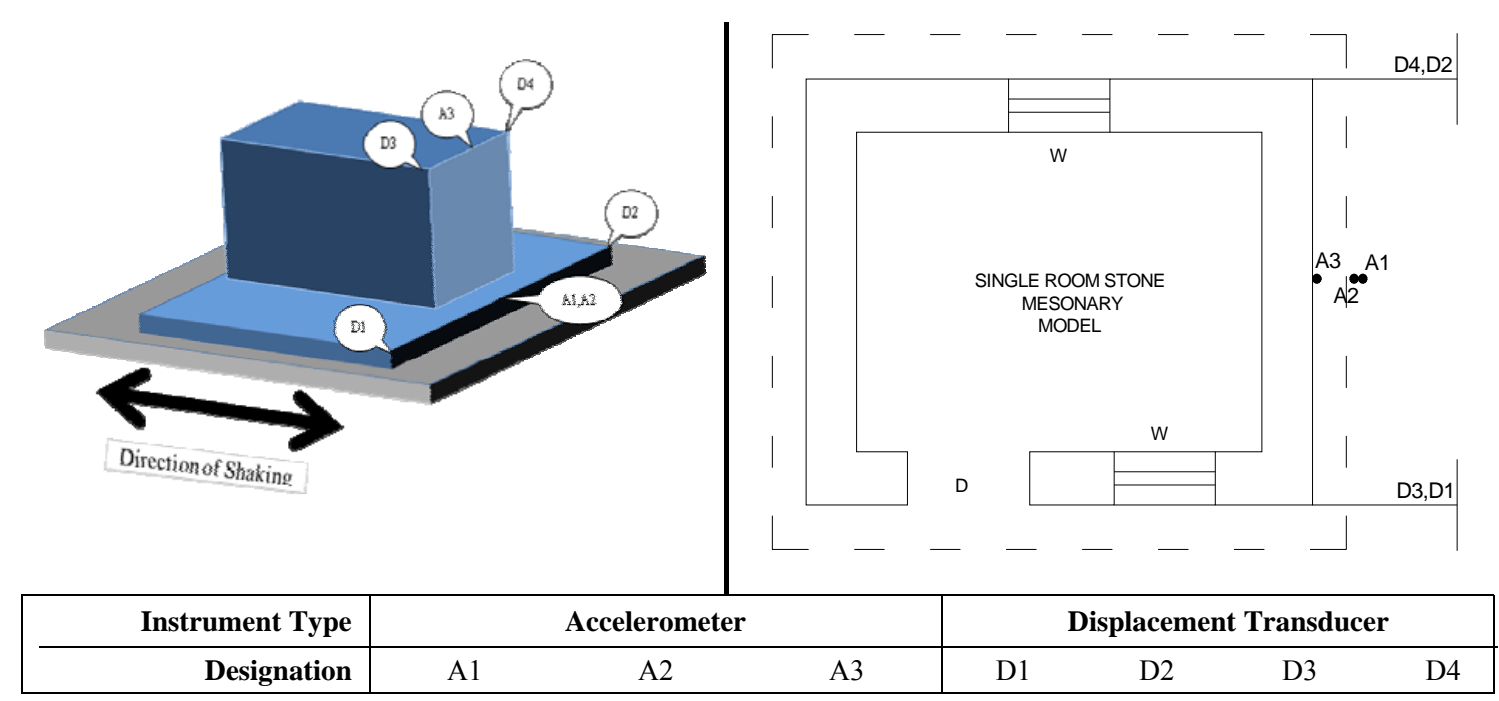

Fig. 4. Testing setup and instrumentation details of the building model tested on shake table at the Earthquake Engineering Center of Peshawar.

gives an estimate of $4.008 \%$ for damping using the positive peaks and $5.404 \%$ using the negative peaks. On average a damping value of $4.71 \%$ is computed, which may be approximated as $5 \%$ for the building model.

\section{Fragility assessment of half-dressed stone DS masonry structures}

\subsection{Seismic assessment framework}

Many available techniques may be employed to derive the fragility functions of structures (Borzi et al., 2008; Calvi et al., 2006; Crowley, 2004; Coburn and Spence, 2002; D'Ayala et al., 1997; Erberik, 2008; Kappos and Panagopoulos, 2010; Porter et al., 2007; Rota et al., 2010, among others). The present study included a fully probabilistic, nonlinear, dynamic reliability-based method (NDRM) recently developed by Ahmad (2011) for the seismic performance evaluation and fragility analysis of considered structure, as employed recently for other structure types (Ahmad et al., 2012a, b). This method is found to provide reasonable estimates of building damageability when compared with earthquake observations in Pakistan (Ahmad et al., 2012c).

The NDRM is a probabilistic method for calculating the damage exceedance probability of structures for a specified ground motion. The method of incremental dynamic analysis (IDA) proposed by Vamvatsikos and Cornell (2002) was used to derive the structure response curve that correlates the shaking intensity with the drift demand. The method incorporates total uncertainties in the drift demand. The drift demand on structure is convolved then with the structure drift capacity for a specified limit state to obtain the exceedance probability of target limit state at a given shaking level. It is carried out for all the intensity levels to allow the derivation of fragility functions.

\subsection{Mathematical modeling}

Other available, more or less sophisticated modeling techniques may be calibrated for global seismic analysis of masonry buildings (Magenes and Fontana, 1998; Galasco et al., 2002; Kappos et al., 2002). However, these methods cannot be confidently extended for seismic response evaluation of rubble masonry buildings due to its complex behavior as observed during the experimental investigation. The present study included single degree of freedom (SDOF) mathematical model for seismic analysis. The SDOF system is assigned with observing the global lateral force-deformation response of the building simulating the lateral stiffness, strength and deformation capacity of the tested building model. Thus, fully respecting the fundamental response parameters importance for global dynamic seismic analysis and response evaluation of buildings (Elnashai and Di-Sarno, 2008).

The SDOF system is assigned with lateral forcedeformation constitutive law, which is derived from the observed response of the model, i.e. the peak drift and the corresponding base shear observed during each test run. The model is assigned with the mass of the building model, which is adjusted to achieve the fundamental vibration pe$\operatorname{riod}\left(T_{0} 0.07 \mathrm{~s}\right)$ of the model as observed during the test. The model is assigned with $5 \%$ elastic viscous damping, as observed during the low amplitude test. For dynamic seismic analysis, the Rayleigh damping model with tangent stiffness proportionality is used in the present study. The system of nonlinear equations in the analysis is solved using the KrylovNewton algorithm (Scott and Fenves, 2010) and the average acceleration Newmark time-stepping method 


\begin{tabular}{|c|c|c|}
\hline \multirow{2}{*}{ Damage States } & \multicolumn{2}{|c|}{ Damage Description and Comparison with EMS Damage Scale } \\
\hline & Present Study & EMS-98 \\
\hline & \multicolumn{2}{|l|}{ Grade-1: DS1 } \\
\hline & $\begin{array}{l}\text { Slight diagonal cracks are initiated in walls } \\
\text { parallel to excitation direction. } \\
\text { Horizontal cracks initiated at the opening base } \\
\text { corner of walls parallel to excitation, likely to } \\
\text { forming short pier. } \\
\text { Horizontal cracks initiated between walls and } \\
\text { roof. } \\
\text { Vertical cracks initiated at the end of walls } \\
\text { parallel to excitation direction, likely to form } \\
\text { failure plane for detachment of walls } \\
\text { perpendicular to excitations i.e. face loaded } \\
\text { walls. } \\
\text { Horizontal cracks initiated in the face loaded } \\
\text { walls at mid-height and top of wall. } \\
\text { Inclined cracks initiated in the face loaded } \\
\text { walls, likely to form a wedge for out-of-plane } \\
\text { failure. }\end{array}$ & $\begin{array}{l}\text { Negligible to slight damage, } \\
\text { No structural damage, slight non- } \\
\text { structural damage. } \\
\text { Hair-line cracks in very few } \\
\text { walls. } \\
\text { Fall of small pieces of plaster } \\
\text { only. } \\
\text { Fall of loose stones from upper } \\
\text { parts of buildings in very few } \\
\text { cases. } \\
\text { Remarks: comparable damage } \\
\text { state. }\end{array}$ \\
\hline & \multicolumn{2}{|l|}{ Grade-2: DS2 } \\
\hline & $\begin{array}{l}\text { Diagonal cracking increased in walls parallel } \\
\text { to excitation direction. } \\
\text { Horizontal cracks developed at the opening } \\
\text { base and top corners of walls parallel to } \\
\text { excitation, short pier is formed. } \\
\text { Horizontal cracks fully developed between } \\
\text { walls and roof. } \\
\text { Inclined cracks developed at the end of walls } \\
\text { parallel to excitation direction, failure plane for } \\
\text { detachment of face loaded wall is developed. } \\
\text { Horizontal cracks fully developed in the face } \\
\text { loaded walls at mid-height and top of wall. } \\
\text { Inclined cracks developed in the face loaded } \\
\text { walls, a wedge for out-of-plane failure is } \\
\text { formed. }\end{array}$ & $\begin{array}{l}\text { Moderate damage, } \\
\text { Slight structural damage, } \\
\text { moderate non-structural damage. } \\
\text { Cracks in many walls. } \\
\text { Fall of fairly large pieces of } \\
\text { plaster. } \\
\text { Partial collapse of chimneys. } \\
\text { Remarks: comparable damage } \\
\text { state. }\end{array}$ \\
\hline & \multicolumn{2}{|l|}{ Grade-3: DS3 } \\
\hline & $\begin{array}{l}\text { Diagonal cracking widened significantly in } \\
\text { walls parallel to excitation direction. } \\
\text { Horizontal cracks developed at the opening } \\
\text { base and top corners of walls parallel to } \\
\text { excitation, short pier is formed to slide and } \\
\text { rock. } \\
\text { Horizontal cracks fully developed between } \\
\text { walls and roof. } \\
\text { Inclined cracks fully developed at the end of } \\
\text { walls parallel to excitation direction, } \\
\text { detachment of face loaded wall is likely to } \\
\text { occur. } \\
\text { Horizontal cracks fully developed in the face } \\
\text { loaded walls at mid-height and top of wall. Top } \\
\text { wall portion is likely to rock. } \\
\text { Inclined and horizontal cracks developed in the } \\
\text { face loaded walls, a wedge is likely to separate. }\end{array}$ & $\begin{array}{l}\text { Substantial to heavy damage, } \\
\text { Moderate structural damage, } \\
\text { heavy non-structural damage. } \\
\text { Large and extensive cracks in } \\
\text { most walls. } \\
\text { Roof tiles detach. Chimneys } \\
\text { fracture at the roof line; failure of } \\
\text { individual non-structural } \\
\text { elements (Partitions, Gable } \\
\text { Walls) } \\
\text { Remarks: conservative damage } \\
\text { state. }\end{array}$ \\
\hline & \multicolumn{2}{|l|}{\begin{tabular}{|l|} 
Grade-4: DS4 \\
\end{tabular}} \\
\hline & $\begin{array}{l}\text { Diagonal cracking widened extensively in } \\
\text { walls parallel to excitation direction. } \\
\text { Horizontal cracks fully formed at the opening } \\
\text { base and top corners of walls parallel to } \\
\text { excitation, short pier is responding through in- } \\
\text { plane sliding and rocking. } \\
\text { The face loaded wall fully detached from walls } \\
\text { parallel to excitation direction, separating a } \\
\text { wing from transverse walls. The face loaded } \\
\text { wall fully developed horizontal crack at the } \\
\text { top, base and mid-height, forming three pivot } \\
\text { points for rocking. } \\
\text { A wedge like portion started falling in out-of- } \\
\text { plane direction from the face loaded walls. } \\
\text { The structure is at the verge of total collapse. }\end{array}$ & $\begin{array}{l}\text { Very heavy damage, } \\
\text { Heavy structural damage, } \\
\text { Very heavy non-structural } \\
\text { damage. } \\
\text { Serious failure of walls; partial } \\
\text { structural failure of roofs and } \\
\text { floors. } \\
\text { Remarks: conservative damage } \\
\text { state. }\end{array}$ \\
\hline
\end{tabular}

Fig. 5. Global damage mechanism of half-dressed stone DS masonry building model retrieved through dynamic shake table test and comparison with the EMS-98 (Grunthal et al., 1998) damage scale. From left to right: observed damage state, damage state label and description of observed and EMS damage scale. 


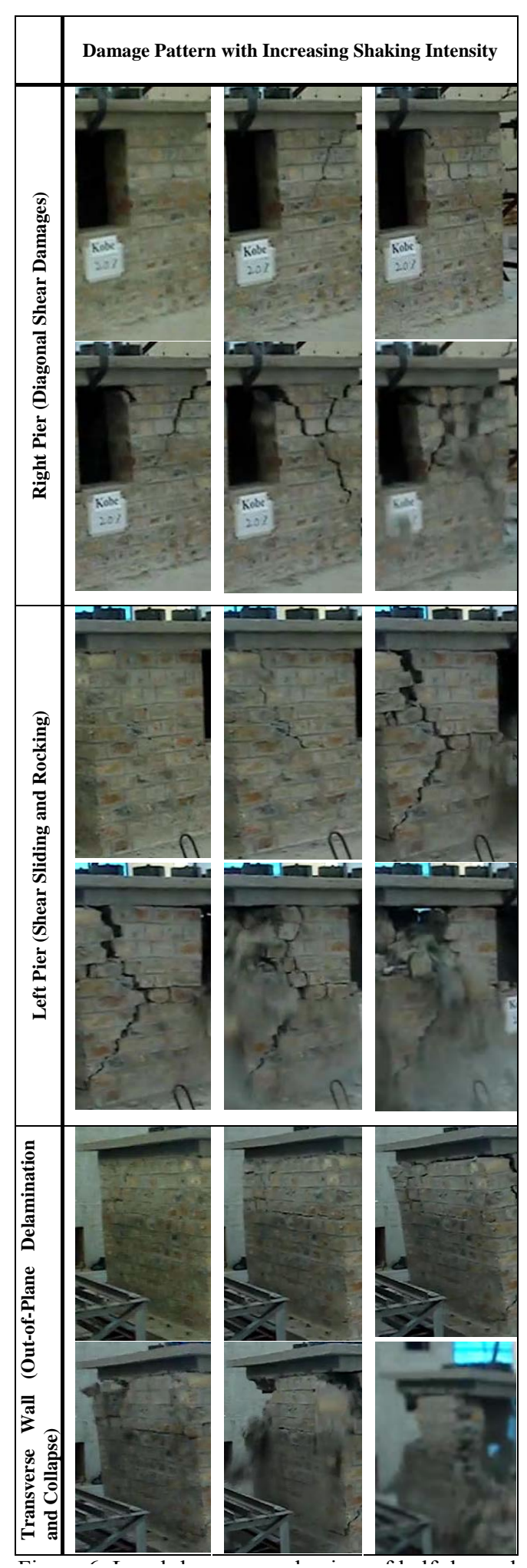

Fig. 6. Local damage mechanism of half-dressed stone DS masonry walls observed during shake table test. From top to bottom: damages observed in in-plane and out-of-plane walls.
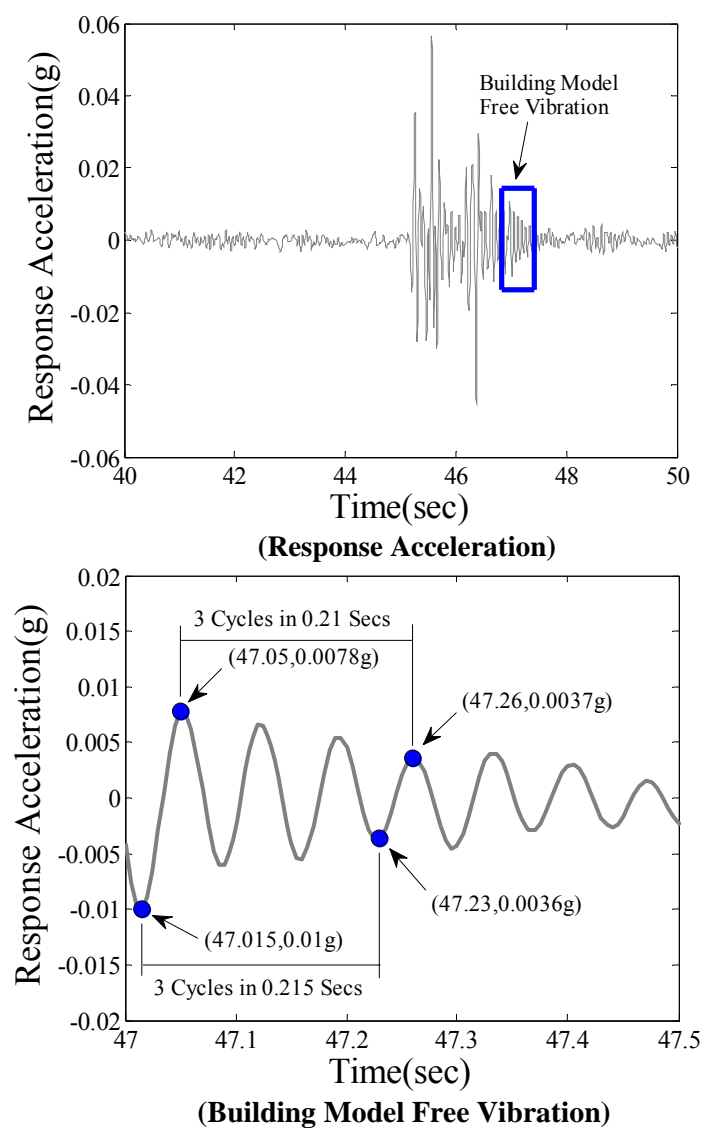

Fig. 7. Dynamic characterization of building model under $0.04 \mathrm{~g}$ input excitation. From top to bottom: model response acceleration and free vibration time history processed for the estimation of building vibration period and elastic damping coefficient.

(Chopra, 2003) with $\gamma=0.5$ and $\beta=0.25$. A time step equal to the sampling size of the ground motion record is considered in the analysis.

Uncertainties that may be observed when considering a group of buildings of the same characteristics are incorporated in the constitutive law through Monte Carlo simulations. In this regard, fifty SDOF systems were generated, which are assigned with random constitutive law. Uncertainties in the lateral stiffness, strength and deformation limits are modeled considering lognormal distribution. The experimentally obtained mechanical properties are considered as the median estimate. A logarithmic standard deviation of 0.25 is considered to model variability in the peak strength, whereas 0.50 logarithmic standard deviation is considered to model variability in the deformation limits. The ratios of the lateral force (i.e., limit state force to the maximum lateral force) and deformation limits (i.e., limit state drift to the first drift limit) of the constitutive law are considered as observed experimentally. The uncertainty in the stiffnesses are considered then accordingly. Figure 8 reports the lateral force-deformation constitutive law obtained experimentally. 


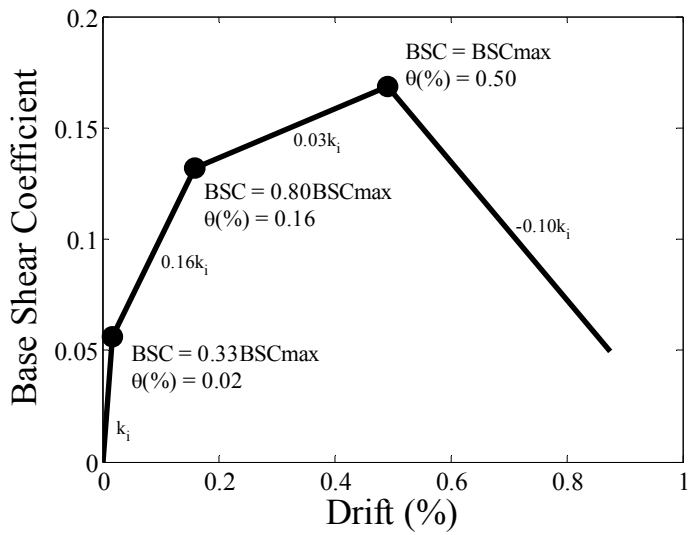

(Experimentally Derived)

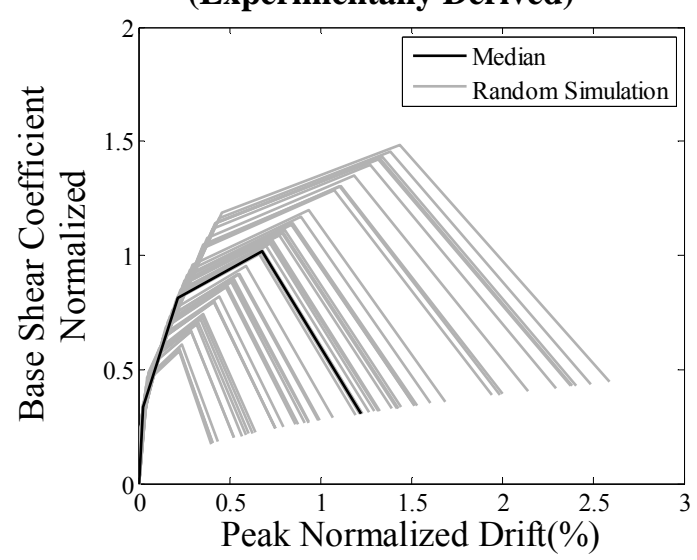

(Randomly Generated, Fifty Simulations)

Fig. 8. Lateral force-deformation constitutive law of DS masonry structures. From top to bottom: constitutive law obtained experimentally and randomly generated for SDOF mechanical model. The lateral force in the later case is normalized by the peak lateral strength.

The randomly simulated constitutive laws assigned to each of the fifty SDOF systems are also shown in Fig. 8.

\subsection{Selection and scaling of accelerograms}

The NDRM method requires accelerograms to perform the nonlinear dynamic time history analysis as part of the IDA of structures. A suite of ten natural accelerograms are obtained from the PEER NGA strong motions database. The acceleration response spectrum of the selected accelerograms is compatible with the building code specified spectrum for type D soil of NEHRP classification (BCP, 2007). The accelerograms were also selected and used elsewhere (Ahmad et al., 2012a, b, c; Menon and Magenes, 2011). The accelerograms are normalized, anchored to common PGA, and linearly scaled to multiple shaking levels for IDA of each SDOF system.
Table 2. Damage scale considered for fragility functions derivation.

\begin{tabular}{ll}
\hline Limit States (LS) versus Damage State (DS) & Drift Limits \\
\hline LS1: Damage level Grade-1 DS1 will be attained. & $\theta_{1}=0.7 \theta_{\mathrm{y}}$ \\
LS2: Damage level Grade-2 DS2 will be attained. & $\theta_{2}=1.5 \theta_{\mathrm{y}}$ \\
LS3: Damage level Grade-3 DS3 will be attained. & $\theta_{3}=0.5\left(\theta_{\mathrm{y}}+\theta_{\mathrm{u}}\right)$ \\
LS4: Damage level Grade-4 DS4 will be attained. & $\theta_{4}=\theta_{\mathrm{u}}$ \\
\hline
\end{tabular}

where $\theta_{\mathrm{i}}$ represents the mean target drift limit states; $\theta_{\mathrm{y}}$ represents the idealized yield drift limit derived from the possible bi-linearization of lateral force-deformation response of model; $\theta_{\mathrm{u}}$ represents the ultimate drift limits. A mean value of $0.16 \%$ is considered for $\theta_{\mathrm{y}}$ and $0.60 \%$ for $\theta_{\mathrm{u}}$. A logarithmic standard deviation of 0.20 is considered for each of the drift limit sates.

\subsection{Fragility functions}

Each SDOF system is analyzed using the selected ground motions scaled to multiple PGA levels. The drift demand for each record and target PGA is obtained for all the SDOF systems. The drift demand is correlated with the corresponding ground motion intensity to derive response curves for each SDOF system under each ground motion record. The mean elastic spectral acceleration, considering all the records for a target PGA, at $0.30 \mathrm{~s}$ is considered as the intensity measure in the present study. Figure 10 shows the response curves obtained for the considered structure class. The drift demand for a specified shaking level takes into account all the uncertainties, material uncertainties and record-to-record variability.

For the fragility functions derivation, the NDRM method computes the limit state probability of exceedance for a specified ground motion through the integration of the joint probability density function of the drift demand and drift capacity. The First Order Reliability Method, FORM, approximations (Der Kiureghian, 2005; Pinto et al., 2004) are employed to obtain the limit state exceedance probability. A damage scale was developed as per recommended of FEMA (2003) for the derivation of fragility functions (see Table 2). The idealized yield drift limit $\theta_{\mathrm{y}}$ was selected such that the damage state between $0.7 \theta_{\mathrm{y}}$ and $1.5 \theta_{\mathrm{y}}$ is a slight damage, as per FEMA (2003) recommendation, which is roughly simulated compared to the observed behavior. The ultimate drift limits $\theta_{\mathbf{u}}$ corresponds to the lateral deformation when the lateral force drops by $20 \%$, as proposed by Magenes and Calvi (1997), which corresponds to the near collapse limit state. This limit state in our study approximately corresponds to the near collapse limit state as the strength drops very rapidly after the ultimate limit state (see Fig. 8).

The FORM approximation is used to obtain the limit state probability of exceedance for various target ground motions. A lognormal cumulative distribution function is assumed, as employed elsewhere (Kircher et al., 1997; Porter et al., 2007), and fitted to the observed points. The median and logarithmic standard deviation of each limit state are obtained, which can be used for fragility derivation (see Fig. 11): 

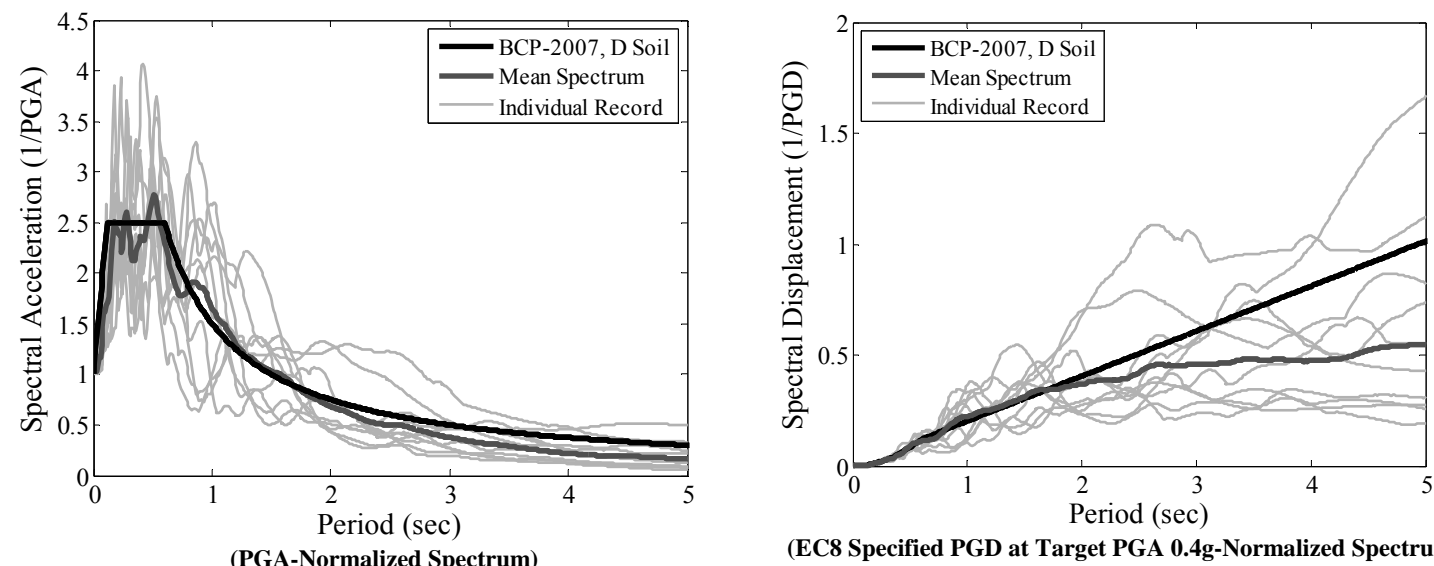

(EC8 Specified PGD at Target PGA 0.4g-Normalized Spectrum)

\begin{tabular}{|c|c|c|c|c|c|c|c|c|}
\hline Record No. & Date & Event & Station/Component & $\begin{array}{c}\text { Moment Magnitude } \\
\text { (Mw) }\end{array}$ & $\begin{array}{l}\text { Distance } \\
(\mathrm{km})\end{array}$ & $\begin{array}{l}\text { Soil Type } \\
\text { (NEHRP) }\end{array}$ & $\begin{array}{l}\text { Duration } \\
\text { (sec) }\end{array}$ & $\begin{array}{c}\text { PGA } \\
(\mathrm{g})\end{array}$ \\
\hline 1 & $4 / 25 / 1992$ & Cape Mendocino & Fortuna - Fortuna Blvd & 7.1 & 23.6 & $\mathrm{C}$ & 44.00 & 0.116 \\
\hline 2 & $6 / 28 / 1992$ & Landers & Desert Hot Springs & 7.3 & 23.2 & $\mathrm{C}$ & 50.00 & 0.154 \\
\hline 3 & $6 / 28 / 1992$ & Landers & Yermo Fire Station & 7.3 & 24.9 & $\mathrm{D}$ & 44.00 & 0.152 \\
\hline 4 & $10 / 18 / 1989$ & Loma Prieta & Hollister Diff. Array & 6.9 & 25.8 & $\mathrm{D}$ & 39.64 & 0.279 \\
\hline 5 & $1 / 17 / 1994$ & Northridge & Beverly Hills & 6.7 & 19.6 & $\mathrm{C}$ & 29.99 & 0.416 \\
\hline 6 & $1 / 17 / 1994$ & Northridge & Canoga Park - Topanga Can & 6.7 & 15.8 & $\mathrm{D}$ & 24.99 & 0.356 \\
\hline 7 & $1 / 17 / 1994$ & Northridge & LA - Hollywood Stor FF & 6.7 & 25.5 & $\mathrm{D}$ & 40.00 & 0.231 \\
\hline 8 & $1 / 17 / 1994$ & Northridge & Sunland - Mt Gleason Ave & 6.7 & 17.7 & $\mathrm{C}$ & 29.99 & 0.157 \\
\hline 9 & $11 / 24 / 1987$ & Superstitn Hills(B) & El Centro Imp. Co. Cent & 6.7 & 13.9 & $\mathrm{D}$ & 40.00 & 0.258 \\
\hline 10 & $11 / 24 / 1987$ & Superstitn Hills(B) & Plaster City & 6.7 & 21.0 & $\mathrm{D}$ & 22.23 & 0.186 \\
\hline
\end{tabular}

(Details of Individual Record)

Fig. 9. Characteristics of the accelerograms used in the present study. From left to right and top to bottom: acceleration response spectrum, displacement response spectrum and details of the individual record.

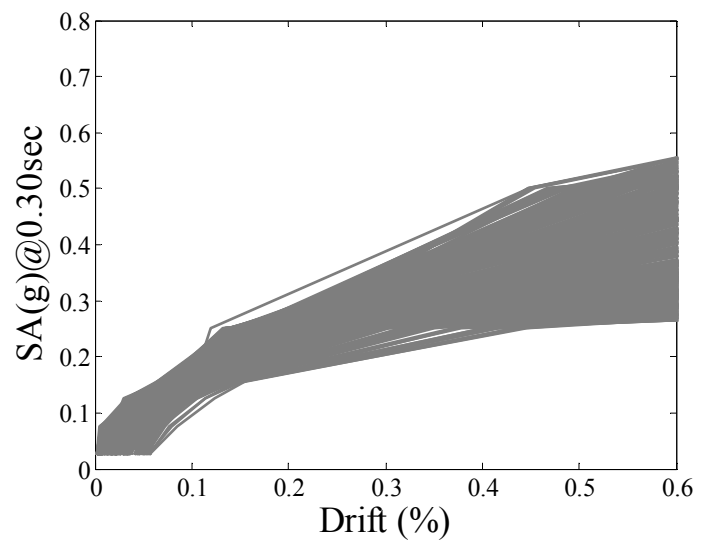

Fig. 10. Structure response curves obtained through IDA of SDOF systems.

$P\left[D \geq d_{\mathrm{LS}} / \mathrm{SA}=s a\right] \Phi\left(\frac{1}{\beta} \operatorname{Ln}\left(\frac{\mathrm{SA}}{\overline{s a}_{\mathrm{LS}}}\right)\right)$,

where $P$ represents the limit state probability of exceedance; $\Phi$ represents the standard normal cumulative distribution function; $\beta$ represents the logarithmic standard deviation of fragility function; SA represents the seismic intensity; and

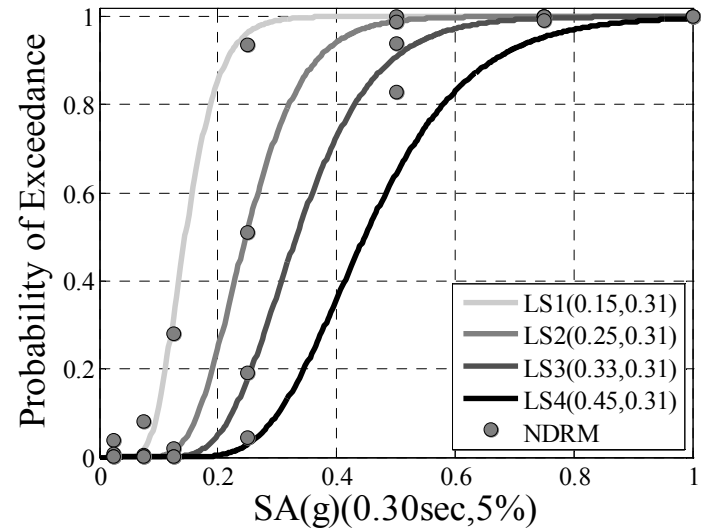

Fig. 11. Fragility functions for Himalayan DS masonry structures obtained through NDRM.

$\overline{s a}_{\mathrm{LS}}$ represents the median estimate of the distribution. The values of $\beta$ and $\overline{s a}_{\mathrm{LS}}$ are also provided in Fig. 11. The functions can be employed in future applications for the damageability assessment of considered DS masonry structures during earthquake induced ground motions. 


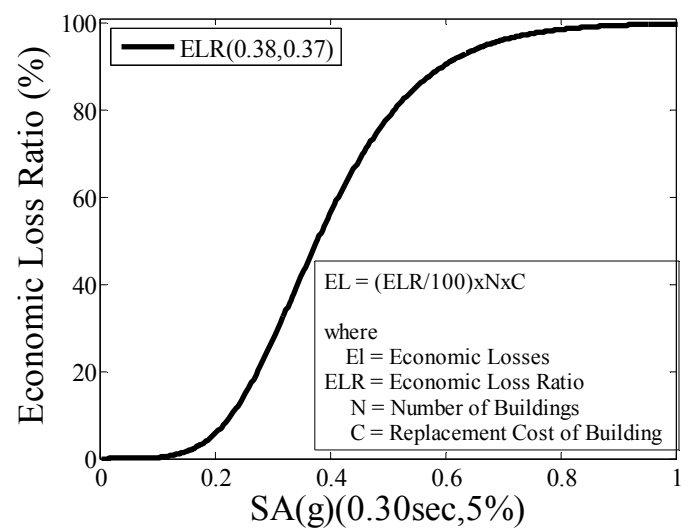

Fig. 12. Vulnerability function for Himalayan DS masonry structures obtained using the FEMA (2003) economic consequence factor.

\subsection{Vulnerability functions}

The impact of an earthquake on the built environment is computed in terms of monetary losses and human casualties. The monetary losses correspond to the economic losses the authority has to bear to bring the devastated society to habitable condition. It includes the direct losses due to building damage and indirect losses, including business downtime and loss of means of income besides the response and relief expenditure. The direct economic losses related to the building damage represent the amount required to pay for the repair, demolishment and replacement of structures damaged in earthquakes (Bal et al., 2008; FEMA, 2003). Only the direct economic losses are considered in the present research study. The human casualties include the number of people injured and trapped in the collapsed buildings which are essential for rescue operation soon after the earthquake (Erdik et al., 2011; Hancilar et al., 2010). The casualties may be further classified into minor, moderate and serious injuries and deaths (Spence, 2007b).

Vulnerability function for economic losses is derived from the building fragility functions. It included the estimation of probability of building damages at a specified shaking intensity, which are convolved with the economic consequence factor ECF (Ahmad, 2012c), where ECF refers to the scale relating building damage with the monetary losses. The FEMA model which assigns a cost ratio (the ratio of damaged building repair to replacement cost) of 0.02 for DS1, 0.10 for DS2, 0.50 for DS3 and 1.0 for DS4, is employed herein to derive vulnerability curve for the considered DS masonry building. Figure 12 reports the vulnerability curve for the considered DS masonry structures where the losses are represented in terms of the economic loss ratio. The function can be used to compute the economic losses for the structures during earthquake given the shaking intensity (SA@0.30s).

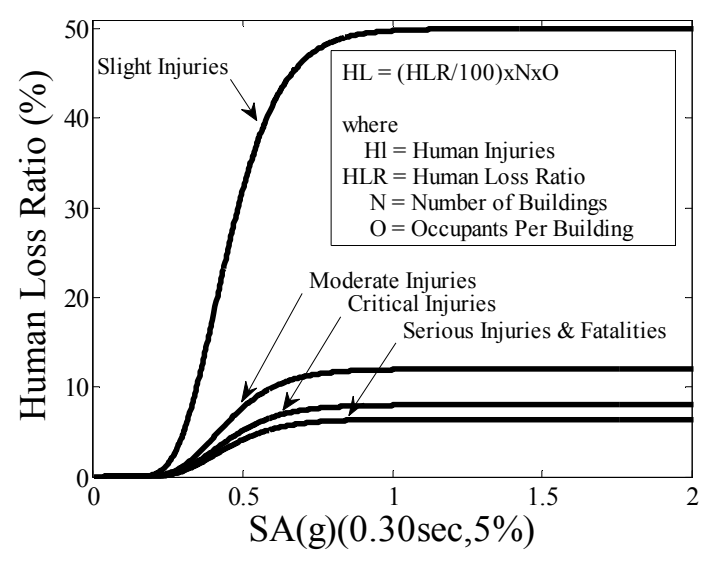

Fig. 13. Vulnerability functions for Himalayan DS masonry structures obtained using the Spence (2007b) human consequence factor.

Vulnerability functions for human casualties are derived from the collapse fragility function of the buildings. For this purpose the human consequence factor (HCF) developed by Spence (2007b) is employed in the present study. It includes the convolution of the collapse fragility function with the loss ratio of the Spence model. This model assigns ratio of slight injuries with 0.50 , moderate injuries with 0.12 , serious injuries with 0.08 and critical injuries and deaths with 0.064 in collapsed buildings. Figure 13 reports the vulnerability functions derived for the casualty estimation in earthquakes. The losses are represented in terms of the Human loss ratio, which can provide estimates of human casualties in collapsed buildings during earthquake given the shaking intensity (SA@ 0.30 s).

\section{Seismic risk of DS masonry structures in scenario earthquakes}

The present study also included case studies for risk assessment of considered DS masonry structures in large scenario earthquakes. Three scenario earthquakes with $M_{\mathrm{w}}=7.0,7.5$ and 8.0 are considered, for which building damageability is assessed at various source-to-site distances. Each of the scenario earthquake ground motions is simulated with 1000 different ground motion fields, considering uncertainties in the ground motions estimate. Empirical ground motion prediction equations (GMPEs) are used to estimate ground motions (Abrahamson and Silva, 2008; Boore and Atkinson, 2008; Campbell and Bozorgnia, 2008).

Damageability of structures is assessed using the previously derived fragility function. For a given earthquake and specified source-to-site distance, the corresponding seismic intensity is obtained using the GMPEs. The associated limit state probability of exceedance is obtained to compute the percentage of structures in various damage states. Figure 14 reports the damage probability matrix, showing the mean 


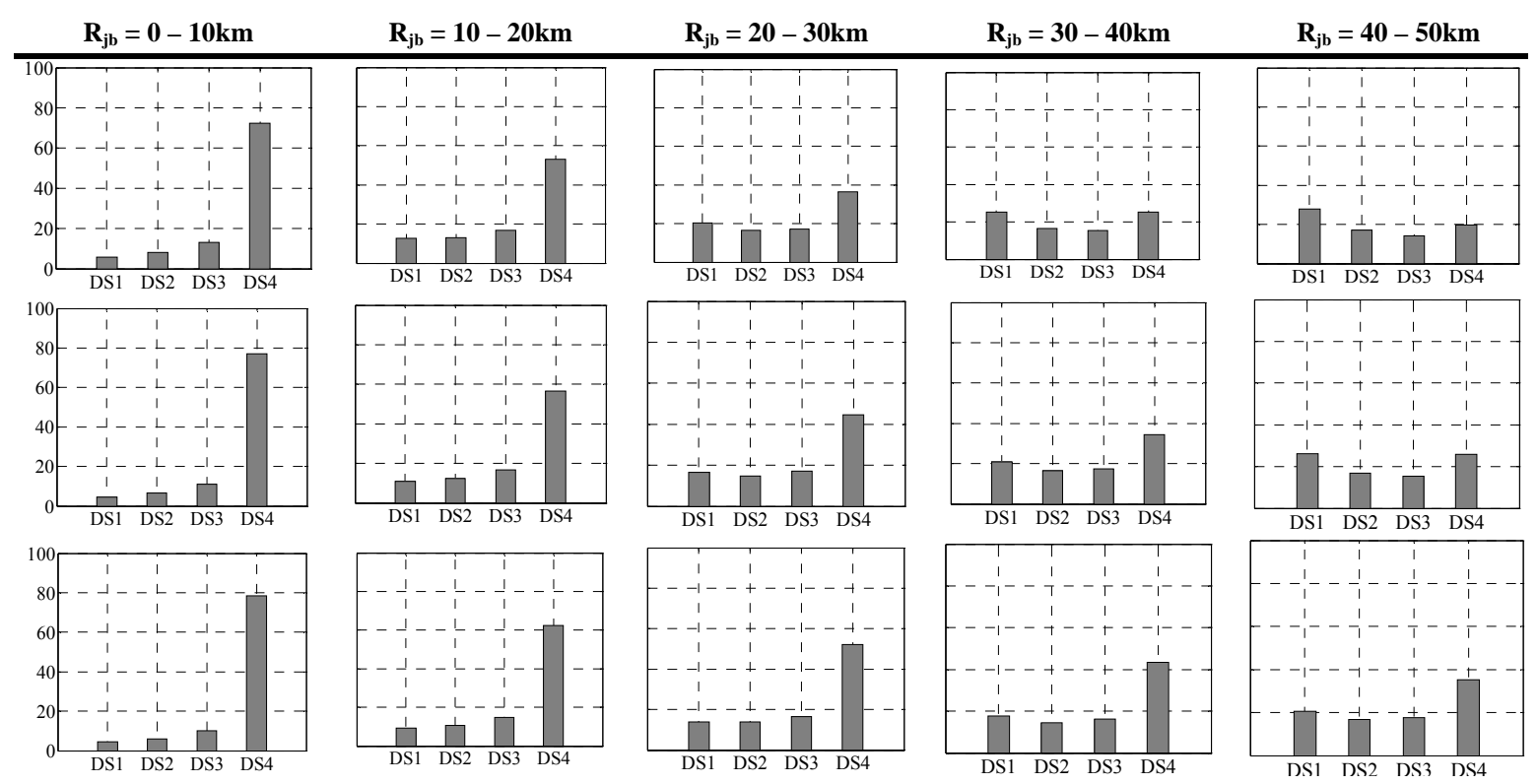

Fig. 14. Damageability (percentage of total stock) of DS masonry structures in scenario earthquakes. From top to bottom: Damageability for $M_{\mathrm{W}}=7.0$, Damageability for $M_{\mathrm{W}}=7.5$ and Damageability for $M_{\mathrm{W}}=8.0$. DS1 represents slight damages; DS2 represents moderate damages; DS3 represents heavy damages.

estimate of the percentage of structures with various damage levels.

The observed damageability of the considered structure type seems very high. It can be observed that more than 40 percent of the stock may collapse during earthquake with $\mathrm{Mw}$ equal or greater than 7.0, for buildings located in the near and intermediate field. The percentage of collapsed structures can even rise to 70-80 during large earthquakes and for buildings located in close source-to-site distance. This huge percentage of damageability will consequently result in highly associated socio-economic losses. This high vulnerability of the considered building type gives merit to the use of simple retrofitting interventions, as investigated by Ali et al. (2012), to mitigate the risk of vulnerable stone masonry buildings in the future expected large earthquake.

\section{Conclusions}

The paper presents a study carried out as part of the research aiming towards risk mitigation and disaster risk reduction in the Himalayan region, which could be subjected to very large earthquakes in the future. Half-dressed masonry structures representing public critical facilities in the region are considered for investigation, a very common type in the region. Fragility functions are derived for the considered construction type using experimental and numerical investigations. Furthermore, vulnerability functions are derived for economic loss estimation and human casualty estimation. The derived fragility and vulnerability functions are employed for earthquake scenario risk assessment consid- ering moderate and large magnitude earthquakes. The considered construction type exhibits high vulnerability against earthquakes. Up to 40 percent of building stock can collapse in large earthquakes, where the percentage of collapse can rise as high as 70-80 for large earthquakes with close sourceto-site distance. The present study can be employed for communicating the expected risk level to public authorities to take measures aiming towards risk mitigation and disaster risk reduction. This can in turn result in the mitigation of economic losses from future earthquakes. The findings from the present study can also be employed for rapid earthquake loss estimation within the context of prompt response to disaster sites, essential for rescue operation and emergency planning that can reduce human casualties in earthquakes.

\section{Supplementary material related to this article is available online at: \\ http://www.nat-hazards-earth-syst-sci.net/12/3441/2012/ nhess-12-3441-2012-supplement.zip.}

Acknowledgements. The reviewers' effort in evaluating the manuscript and kindly providing encouraging remarks is highly appreciated. The experimental study presented herein is financially supported by the Board of Advanced Studies and Research (BOASAR) of the University of Engineering \& Technology (UET) Peshawar and the Higher Education Commission (HEC) of Pakistan, which are gratefully acknowledged.

Edited by: M. E. Contadakis

Reviewed by: J. M. Dulinska, T. Makarios, and

one anonymous referee 


\section{References}

Abrahamson, N. and Silva, W.: Summary of the Abrahamson and Silva NGA ground-motion relations, Earthq. Spectra, 24, 67-97, 2008.

Adanur, S.: Performance of masonry buildings during the 20 and 27 December 2007 Bala (Ankara) earthquakes in Turkey, Nat. Hazards Earth Syst. Sci., 10, 2547-2556, doi:10.5194/nhess-102547-2010, 2010.

Ahmad, N.: Seismic risk assessment and loss estimation of building stock of Pakistan, PhD Thesis, ROSE School-IUSS Pavia, Pavia, Italy, 2011.

Ahmad, N., Ali, Q., Ashraf, M., Naeem, A., and Alam, B. Seismic performance evaluation of reinforced plaster retrofitting technique for low-rise block masonry structures, Int. J. Earth Sci. Eng., 5, 193-206, 2012a.

Ahmad, N., Ali, Q., and Umar, M.: Seismic vulnerability assessment of multistorey timber braced frame traditional masonry structures, Appl. Mech. Materials - Trans Tech Publications, accepted, 2012b.

Ahmad, N., Ali, Q., Crowley, H., and Pinho, R. Earthquake loss estimation of structures in Pakistan, in Proceedings of the 9CUEE \& 4ACEE, Tokyo, Japan, 2012c.

Akkar, S., Aldemir, A., Askan, A., Bakir, S., Canbay, E., Demirel, I. O., Erberik, M. A., Gulerce, Z., Gulkan, P., Kalkan, E., Prakash, S., Sandikkaya M. A., Sevilgen, V., Ugurhan, B., and Yenier, E.: 8 March 2010 Elazı g-Kovanc $ı$ lar (Turkey) Earthquake: Observations on Ground Motions and Building Damage, Seismol. Res. Lett., 82, 42-58, 2011.

Ali, Q. and Mohammad, T. Stone masonry residential buildings in northern areas of Pakistan. Housing Report, Earthquake Engineering Research Institute (EERI), Oakland, CA, USA, 2006.

Ali, Q., Naeem, A., Ashraf, M., Ahmed, A., Alam, B., Ahmad, N., Fahim, M., Rahman, S., and Umar, M.: Seismic performance of stone masonry buildings used in the Himalayan Belt, Earthq. Spectra, accepted, , 2012.

Avouac, J., Ayoub, F., Leprince, S., Konca, O., and Helmberger, D. V.: The 2005 Mw 7.6 Kashmir earthquake: Sub-pixel correlation of ASTER images and seismic waveforms analysis, Earth Planet. Sci. Lett., 249, 514-528, 2006.

Bal, I. E., Crowley, H., Pinho, R., and Gulay, G.: Detailed Assessment of Structural Characteristics of Turkish RC Building Stock for Loss Assessment Model, Soil Dynam. Earthquake Eng., 28, 914-932, 2008.

BCP-2007: Building Code of Pakistan-Seismic provision 2007, Technical Document, Ministry of Housing and Works, Islamabad, Pakistan, 2007.

Bilham, R.: Earthquakes in India and in the Himalaya: tectonic, geodesy, and history, Ann. Geophys., 47, 839-858, 2004, http://www.ann-geophys.net/47/839/2004/.

Boore, D. M. and Atkinson, G. M.: Ground-motion prediction equations for the average horizontal component of PGA, PGV, and $5 \%$-damped PSA at spectral periods between $0.01 \mathrm{~s}$ and $10.0 \mathrm{~s}$, Earthq. Spectra, 24, 99-138, 2008.

Borzi, B., Crowley, H., and Pinho, R. Simplified pushover-based earthquake loss assessment (SP-BELA) method for masonry buildings, Int. J. Architectural Heritage, 2, 353-376, 2008.

Bothara, J. and Brzev, S. A. Tutorial: Improving the seismic performance of stone masonry buildings, Earthquake Engineering Research Institute (EERI), Oakland, CA, USA, 2011.
Calvi, G. M., Pinho, R., Magenes, G., Bommer, J. J., RestrepoVelez, L. F., and Crowley, H.: Development of seismic vulnerability assessment methodologies over the past 30 years, ISET J. Earthqu. Technol., 43, 75-104, 2006.

Campbell, K. and Bozorgnia, Y.: NGA ground motion model for the geometric mean horizontal component of PGA, PGV, PGD and $5 \%$ damped linear elastic response spectra for periods ranging from 0.01 to 10s, Earthq. Spectra, 24, 139-171, 2008.

Chopra, A. K.: Dynamics of structures: Theory and applications to earthquake engineering, 3rd Edition, Prentice-Hall, NJ, USA, 2003.

Coburn, A. and Spence, R. Earthquake Protection. John Wiley and Sons, Ltd., West Sussex, England, 2002.

Crowley, H., Pinho, R., and Bommer, J. J.: A probabilistic displacement-based vulnerability assessment procedure for earthquake loss estimation, Bull. Earthq. Eng., 2, 173-219, 2004.

D’Ayala, D., Spence, R., Oliveira, C., and Pomonis, A. Earthquake loss estimation for Europe's historic town centers, Earthq. Spectra, 13, 773-793, 1997.

Der Kiureghian, A.: First- and second-order reliability methods, edited by: Nikolaidis, E., Ghiocel, D. M., and Singhal, S., in: Engineering Design Reliability Handbook, CRC Press 2005.

EERI: Learning from Earthquakes: The Kashmir earthquake of October 8, 2005: impacts in Pakistan. EERI Special Earthquake Report, Earthquake Engineering Research Institute (EERI), Oakland, CA, USA, 2006.

EERI: Learning from Earthquakes: The Mw 6.9 Sikkim-Nepal border earthquake of September 18, 2011. EERI Special Earthquake Report, Earthquake Engineering Research Institute (EERI), Oakland, CA, USA, 2012.

Elnashai, A. S. and Di-Sarno, L.: Fundamentals of earthquake engineering. John Wiley and Sons Ltd., West Sussex, UK, 2008.

Erberik, M. A.: Generation of fragility curves for Turkish masonry buildings considering in-plane failure modes, Earthquake Eng. Struct. Dynam., 37, 387-405, 2008.

Erdik, M., Sesetyan, K., Demircioglu, M. B., Hancilar, U., and Zulfikar, C. Rapid earthquake loss assessment after damaging earthquakes, Soil Dynam. Earthq. Eng., 31, 247-266, 2011.

FEMA: Multi-hazard loss estimation methodology, earthquake model. HAZUS-MH Technical Manual, Federal Emergency Management Agency (FEMA), Washington, DC, USA, 2003.

Galasco, A., Lagomarsino, S., and Penna, A.: TREMURI Program: Seismic analyses of 3D masonry buildings, University of Genoa, Genoa, Italy, 2002.

Grunthal, G., Musson, R. M. W., Schwarz, J., and Stucchi, M.: EMS-98: European Macroseismic Scale, Centre Europèen de Géodynamique et de Séismologie, Luxembourg, 1998.

Gulkan, P., Sucuoglu, H., and Ergunay, O.: Earthquake vulnerability, loss and risk assessment in Turkey. Proceedings of the Tenth World Conference on Earthquake Engineering, Madrid, Spain, 1992.

Gupta, I., Shankar, R., and Sinvhal, A. Earthquake vulnerability assessment of house constructions in Himalayas, J. Design Built Environ, 3, 1-14, 2008.

Hancilar, U., Tuzun, C., Yenidogan, C., and Erdik, M.: ELER software - a new tool for urban earthquake loss assessment, Nat. Hazards Earth Syst. Sci., 10, 2677-2696, doi:10.5194/nhess-102677-2010, 2010. 
Ingham, J. and Griffith, M. C.: The Performance of Unreinforced Masonry Buildings in the 2010/2011 Canterbury Earthquake Swarm, Technical Report, Royal Commissions and Commissions of Inquiry, Wellington, New Zealand, 2011.

Javed, M., Naeem, A. and Magenes, G.: Performance of masonry structures during earthquake-2005 in Kashmir, Mehran University Res. J. Eng. Technol., 27, 271-282, 2008.

Kappos, A. and Panagopoulos, G.: Fragility curves for reinforced concrete buildings in Greece. Structure and Infrastructure Engineering: Maintenance, Management, Life-Cycle Design and Performance, 6, 39-53, 2010.

Kappos, A. J., Penelis, G. G., and Drakopoulos, C. G.: Evaluation of simplified models for lateral load analysis of unreinforced masonry buildings, J. Struct. Eng., 128, 890-897, 2002.

Kaushik, H. B., Dasgupta, K., Sahoo, D. R., and Kharel, G.: Performance of structures during the Sikkim earthquake of 14 February 2006, Curr. Sci., 91, 449-455, 2006.

Kircher, C. A., Nassar, A. A., Kustu, O., and Holmes, W. T.: Development of building damage functions for earthquake loss estimation, Earthq. Spectra, 13, 663-682, 1997.

Magenes, G. and Calvi, G. M.: In-plane seismic response of brick masonry walls, Earthq. Eng. Struct. Dynam., 26, 1091-1112, 1997.

Magenes, G. and Fontana, D.: Simplified non-linear seismic analysis of masonry buildings, Proc. British Masonry Soc., 5, 190195, 1998.

Maqsood, S. T. and Schwarz, J.: Seismic vulnerability of existing building stock in Pakistan. Proceedings of the Fourteenth World Conference on Earthquake Engineering, Beijing, China, 2008.

Menon, A. and Magenes, G.: Definition of seismic input for out-ofplane response of masonry walls: I. parametric study, J. Earthq. Eng., 15, 165-194, 2011.
Murty, C. V. R.: Earthquake Tips: Learning seismic design and construction. Technical Report, Indian Institute of Technology, Kanpur, Uttar Pradesh, India, 2003.

Naseer, A., Naeem, A., Hussain, Z., and Ali, Q. Observed seismic behavior of buildings in northern Pakistan during the 2005 Kashmir earthquake, Earthq. Spectra, 26, 425-449, 2010.

Pinto, P. E., Giannini, R., and Franchin, P.: Seismic reliability analysis of structures. IUSS Press, Pavia, Italy, 2004.

Porter, K., Kennedy, R., and Bachman, R.: Creating fragility functions for performance-based earthquake engineering, Earthq. Spectra, 23, 471-489, 2007.

Rai, D. C. and Murthy, C. V. R.: Preliminary report on the 2005 north Kashmir earthquake of October 8, 2005. Field Report, Indian Institute of Technology, Kanpur, Uttar Pradesh, India, 2006.

Rota, M., Penna, A., and Magenes, G.: A methodology for deriving analytical fragility curves for masonry buildings based on stochastic nonlinear analyses, Eng. Struct., 32, 1312-1323, 2010.

Scott, M. H. and Fenves, G. L.: A Krylov Subspace Accelerated Newton Algorithm: application to dynamic progressive collapse simulation of frames, J. Struct. Eng., 136, 473-480, 2010.

Spence, R.: Saving lives in earthquakes: successes and failures in seismic protection since 1960, Bulletin Earthq. Eng., 5, 139-251, 2007a.

Spence, R.: Earthquake disaster scenario predictions and loss modelling for urban areas, LESSLOSS Report, IUSS Press, Pavia, Italy, 2007b.

Tomazevic, M.: Some aspects of experimental testing of seismic behavior of masonry walls and models of masonry buildings, ISET J. Earthq. Technol., 37, 101-117, 2000.

Vamvatsikos, D. and Cornell, C.: Incremental dynamic analysis, Earthq. Eng. Struct. Dynam., 31, 491-514, 2002. 